\title{
Influence of Nodal signalling on pluripotency factor expression, tumour cell proliferation and cisplatin-sensitivity in testicular germ cell tumours
}

K. Harpelunde Poulsen ${ }^{1,2}$, J. E. Nielsen ${ }^{1,2}$, B. Grønkær Toft ${ }^{3}$, U. N. Joensen ${ }^{4}$, L. J. Rasmussen ${ }^{5}$, M. Blomberg Jensen ${ }^{1}$, R. T. Mitchell ${ }^{6}$ A. Juul ${ }^{1,2}$, E. Rajpert-De Meyts ${ }^{1,2}$ and A. Jørgensen ${ }^{1,2^{*}}$

\begin{abstract}
Background: Testicular germ cell tumours (TGCTs) are characterised by an overall high cisplatin-sensitivity which has been linked to their continued expression of pluripotency factors. Recently, the Nodal signalling pathway has been implicated in the regulation of pluripotency factor expression in fetal germ cells, and the pathway could therefore also be involved in regulating expression of pluripotency factors in malignant germ cells, and hence cisplatin-sensitivity in TGCTs.

Methods: We used in vitro culture of the TGCT-derived cell line NTera2, ex vivo tissue culture of primary TGCT specimens and xenografting of NTera2 cells into nude mice in order to investigate the consequences of manipulating Nodal and Activin signalling on pluripotency factor expression, apoptosis, proliferation and cisplatinsensitivity.

Results: The Nodal signalling factors were markedly expressed concomitantly with the pluripotency factor OCT4 in GCNIS cells, seminomas and embryonal carcinomas. Despite this, inhibition of Nodal and Activin signalling either alone or simultaneously did not affect proliferation or apoptosis in malignant germ cells in vitro or ex vivo. Interestingly, inhibition of Nodal signalling in vitro reduced the expression of pluripotency factors and Nodal pathway genes, while stimulation of the pathway increased their expression. However, cisplatin-sensitivity was not affected following pharmacological inhibition of Nodal/Activin signalling or siRNA-mediated knockdown of the obligate co-receptor CRIPTO in NTera2 cells in vitro or in a xenograft model.

Conclusion: Our findings suggest that the Nodal signalling pathway may be involved in regulating pluripotency factor expression in malignant germ cells, but manipulation of the pathway does not appear to affect cisplatinsensitivity or tumour cell proliferation.
\end{abstract}

Keywords: Nodal and Activin signalling, Expression of pluripotency factors, GCNIS, Testicular cancer, Cisplatin-sensitivity

\footnotetext{
* Correspondence: aj@rh.regionh.dk

'Department of Growth and Reproduction, Copenhagen University Hospital

(Rigshospitalet), Blegdamsvej 9, DK-2100 Copenhagen, Denmark

${ }^{2}$ International Research and Research Training Centre in Endocrine Disruption

of Male Reproduction and Child Health (EDMaRC), Blegdamsvej 9,

Copenhagen, Denmark

Full list of author information is available at the end of the article
}

(c) The Author(s). 2020 Open Access This article is licensed under a Creative Commons Attribution 4.0 International License, which permits use, sharing, adaptation, distribution and reproduction in any medium or format, as long as you give appropriate credit to the original author(s) and the source, provide a link to the Creative Commons licence, and indicate if changes were made. The images or other third party material in this article are included in the article's Creative Commons licence, unless indicated otherwise in a credit line to the material. If material is not included in the article's Creative Commons licence and your intended use is not permitted by statutory regulation or exceeds the permitted use, you will need to obtain permission directly from the copyright holder. To view a copy of this licence, visit http://creativecommons.org/licenses/by/4.0/. The Creative Commons Public Domain Dedication waiver (http://creativecommons.org/publicdomain/zero/1.0/) applies to the data made available in this article, unless otherwise stated in a credit line to the data. 


\section{Background}

Testicular germ cell tumours (TGCTs) in young adults originate from a common precursor, germ cell neoplasia in situ (GCNIS, previously known as carcinoma in situ) [1-3]. GCNIS cells are considered to be transformed gonocytes that have failed to differentiate to pre-spermatogonia during fetal testis development, most likely as a consequence of altered signalling from the somatic niche [3]. The arrest of gonocyte maturation is regarded as the initial step in the testicular cancer pathogenesis and results in the presence of a sub-population of cells with retained expression of pluripotency factors in postnatal life [1-3]. Around puberty, the hormonal changes and re-organisation of the testes required to support spermatogenesis are hypothesised to promote increased proliferation and gain of invasive capacity of the GCNIS cells, resulting subsequently in formation of TGCTs. The two main types of TGCTs are seminoma (SEM) and non-seminoma (non-SEM), where the latter may contain undifferentiated embryonal carcinoma (EC) as well as the more differentiated yolk sac tumour (YST), choriocarcinoma ( $\mathrm{CHC}$ ) and teratoma (TER) components [4].

Treatment of TGCTs depends on the tumour subtype and stage, with generally excellent cure rates even for advanced disease. In most cases, orchiectomy followed by surveillance is sufficient, but TGCTs that metastasise (most often non-SEMs) may require a combination of surgery, chemotherapy and in a few cases radiation therapy [5]. TGCTs are generally highly sensitive to cisplatinbased chemotherapy presumably due to their fetal germ cell origin, but the mechanisms underlying this overall high cisplatin-sensitivity of TGCTs and occasional treatment resistance, are not understood in detail $[6,7]$. An association between the embryonic phenotype of the majority of TGCTs and high cisplatin-sensitivity has been established, whereas the differentiated types of TGCTs, such as TER and CHC, are generally considered more resistant to treatment [8]. The relationship between expression of pluripotency factors and cisplatin-sensitivity has also been examined in a TGCT-derived EC cell line, in which loss of pluripotency factor expression by siRNAmediated knockdown of OCT4, resulted in decreased sensitivity to cisplatin [9]. Moreover, treatment with retinoic acid to induce differentiation of the EC-derived NTera2 cell line along the neuroectodermal lineage, resulted in decreased expression of the pluripotency factor OCT4 and increased cisplatin-resistance [10-12], thus supporting the association between pluripotency factor expression and cisplatin-sensitivity. Although cisplatin-based chemotherapy has provided high cure rates for TGCTs, the treatment regimen is associated with long-term complications, including cardiovascular side effects and infertility as well as relapse $[5,13]$. Therefore, optimisation of the current treatment regimen would be beneficial.
Despite the general understanding that expression of pluripotency factors is a hallmark of GCNIS and the majority of TGCTs, the underlying molecular mechanisms responsible for the maintenance or re-activation of pluripotency factor expression in these malignant germ cells are not well understood. Several independent studies have implicated the Nodal signalling pathway in the pathogenesis of TGCTs [12, 14-19]. Recently, we found that stimulation of the Nodal pathway in human fetal testes prolonged the expression of OCT4 in gonocytes, thus directly implicating the pathway in the regulation of the gonocyte to pre-spermatogonia transition during human fetal testis development [19] and involvement in regulating pluripotency factor expression in fetal germ cells (reviewed in [20]). Furthermore, high expression of the Nodal signalling factors NODAL, LEFTY1 and CRIPTO has been reported in GCNIS cells, TGCTs and TGCTderived cell lines $[12,16,17]$, and several studies have found co-expression of Nodal signalling and pluripotency factors in NTera2 cells $[12,15]$. Also, heterogeneous expression of the co-receptor CRIPTO was found in NTera2 cells, with highest expression in the subpopulation of cells displaying the most tumorigenic potential [15].

Nodal and Activin signal through essentially the same receptors, including the activin receptors type 1 (Alk4/7) and type 2 (ActRIIA/IIB). An important difference is that Nodal also requires the presence of the co-receptor Cripto for signal transduction. Among the target genes of the Nodal pathway are Nodal itself and the endogenous inhibitor Lefty1/2, which blocks the formation of the receptor complex by binding Nodal directly or by interacting with Cripto [21]. The endogenous inhibitor of Activin signalling is Follistatin, which binds directly to Activin to inhibit this pathway. In recent years, Nodal signalling has emerged as a promising therapeutic target due to its aberrant re-expression and signalling in various types of cancers, including breast cancer, melanoma, prostate cancer and pancreatic cancer [22-26]. Interestingly, we found that simultaneous inhibition of Nodal and Activin signalling resulted in an almost complete loss of gonocytes in human fetal testes [19]. Despite the implication of the Nodal signalling pathway in the pathogenesis of TGCTs, the mechanisms by which this signalling pathway is dysregulated in TGCTs remain to be elucidated. Therefore, we hypothesised that dysregulation of the Nodal signalling pathway is involved in the regulation of pluripotency factor expression and proliferation in malignant germ cells, and thus is associated with the characteristically high cisplatin-sensitivity of these cells.

\section{Methods}

The aim of the this study was to investigate the involvement of Nodal signalling in the regulation of pluripotency factor expression, tumour cell proliferation and 
cisplatin-sensitivity in malignant germ cells by experimental manipulation of this pathway in NTera2 cells in vitro and in a xenograft model as well as in primary ex vivo cultures of adult testis tissue containing GCNIS cells.

\section{Human tissue sample collection and preparation}

Tissue samples used in this study were collected according to the Helsinki Declaration following approval by the regional ethics committee (H-1-2012-007) and all patients gave their informed written and oral consent prior to surgery. Testicular tissue with and without presence of GCNIS cells and testicular tumour samples were obtained after orchiectomy for testicular cancer. Tissue samples were transported to the Pathology Department (Copenhagen University Hospital) immediately after the orchiectomy where a pathologist examined the testes, dividing it into tumour and macroscopically normal areas. The majority of the tissue was used for diagnostic evaluation, while the remaining tissue was allocated to research and either snap-frozen and stored at $-80^{\circ} \mathrm{C}$ or fixed in formalin or Bouin's fixative. Alternatively, the collected testis tissues were placed in cell culture media, immediately transported to the laboratory and set up in ex vivo culture as described below. Testis specimens included samples of 'normal testis (NT)', samples containing GCNIS, SEM, EC and TER (only used for gene expression analysis). Tissue fragments with normal morphology and containing complete spermatogenesis without the presence of malignant germ cells were used as 'normal adult testis' controls. All tissue samples were evaluated by an experienced pathologist using a panel of immunohistochemical markers to characterise GCNIS cells and tumour subtypes, including placental-like alkaline phosphatase (PLAP), podoplanin (PDPN/D2-40), OCT4 (POU5F1), and (for non-SEMs only) also alpha-fetoprotein (AFP) and beta-choriogonadotropin (hCG) [27]. Frozen tissue specimens used for gene expression analysis were sectioned from each end of the tissue fragment and evaluated using immunohistochemistry to confirm the histological tumour subtype prior to RNA extraction.

\section{Immunohistochemistry}

Immunohistochemistry on formalin-fixed tissue was performed as previously described in detail [28]. The fixed tissue samples were dehydrated, paraffin-embedded and sectioned $(4 \mu \mathrm{m})$. Immunohistochemistry on Bouin's fluid-fixed testicular tissue, TGCT samples and formalin-fixed NTera2 cells grown on glass slides was conducted using a pressure cooker for antigen-retrieval as previously described [19]. Visualisation was performed with ImmPACT DAB peroxidase substrate (Vector Laboratories, Burlingame, CA, US). Primary antibodies, dilutions and retrieval buffers are listed in Table 1. All sections were counterstained with Mayer's haematoxylin before mounting with Aquatex (Merck, Kenilworth, NJ, US). Positive and negative controls were included for both protocols. Positive control samples included tissue/cells known to express the studied protein, including OCT4 (adult testes with GCNIS cells), NODAL, CRIPTO, LEFTY (mouse fetal testes and EC tumours), cPARP (adult testes, nuclease-treated) and BrdU (fetal testis culture, BrdUtreated). Negative controls were processed with the primary antibody replaced by the dilution buffer alone with none of the negative controls exhibiting any staining. Sections were evaluated using a Nikon Microphot-FXA microscope, subsequently scanned using a Nano-Zoomer 2.0 HT (Hamamatsu Photonics, Herrsching am Ammersee, Germany) and analysed using the software NDPview version 1.2.36 (Hamamatsu Photonics).

\section{Quantitative RT-PCR}

Quantitative RT-PCR (RT-qPCR) was performed as previously described [19] using the QuantStudio 3 RealTime PCR System (Thermo Fisher, Rochester, NY, US). In brief, mRNA was extracted from frozen tissue specimens and cell lines using the RNAqueous Micro Kit (Ambion, Austin, TX, US) or Nucleospin RNA purification kit (Macherey-Nagel, Düren, Germany), respectively. cDNA was synthesised using $1 \mu \mathrm{g}$ mRNA, a dT20 primer and random hexamers, resulting in $100 \mu \mathrm{l}$ cDNA, with $1 \mu \mathrm{l}$ cDNA used for each RT-qPCR reaction. Gene expression was analysed using specific primers (Table 2) designed to span intron-exon boundaries. All primers had previously been verified (Eurofins Genomics, Ebersberg, Germany). cDNA

Table 1 Antibody dilutions, retrieval buffer and details. Antigen-retrieval buffers: citrate buffer, 10 mM, pH 6.0; TEG buffer, 10 mM Tris, 0.5 mM EGTA, pH 9.0

\begin{tabular}{llllll}
\hline Antibody & Dilution & Retrieval buffer & Species & Company & Cat. Number \\
\hline OCT4 & $1: 50$ & TEG & Mouse & Santa Cruz & Sc-5279 \\
NODAL & $1: 800$ & Citrate & Mouse & Abcam & Ab55676 \\
CRIPTO & $1: 200$ & Citrate & Rabbit & Abcam & Ab19917 \\
LEFTY & Citrate & Rabbit & Abcam & Ab22569 \\
CPARP & $1: 4000$ & Citrate & Rabbit & Cell Signaling & 5625 \\
BrdU & $1: 100$ & Citrate & Mouse & Dako & M0744 \\
\hline
\end{tabular}


Table 2 Primer sequences

\begin{tabular}{lllll}
\hline Gene & Forward primer 5'-3' & Reverse primer 5'-3' & Amplicon size & $\begin{array}{l}\text { GenBank } \\
\text { Accession no. }\end{array}$ \\
\hline OCT4 (POU5F1) & TACTCCTCGGTCCCTTTCC & CAAAAACCCTGGCACAAACT & 166 bp & NM_002701 \\
NANOG & TGATTTGTGGCCTGAAGAAAA & GAGGCATCTCAGCAGAAGACA & 60 bp & NM_024865.4 \\
NODAL & AGCATGGTTTGGAGGTGAC & CCTGCGAGAGGTTGGAGTAG & $160 \mathrm{bp}$ & NM_001329906.1 \\
CRIPTO & TCCTTCTACGGACGGAACTG & ATCACAGCCGGGTAGAAATG & $153 \mathrm{bp}$ & NM_001174136.1 \\
LEFTY1 & GCCTCGACAGTGCATCGCCTC & CAAGTAAACAATGACACATTGGGC & $477 \mathrm{bp}$ & NM_020997.4 \\
RPS20 & AGACTTTGAGAATCACTACAAGA & ATCTGCAATGGTGACTTCCAC & $179 \mathrm{bp}$ & NM_001023 \\
RPS29 & CGCTCTTGTCGTGTCTGTTCA & CCTTCGCGTACTGACGGAAA & 91 bp & NM_001032 \\
\hline
\end{tabular}

used for gene expression analysis in this study have also been used in a previous study [29]. RT-qPCR analyses were measured as duplicates and triplicates for frozen tissue specimens and cell line RNA extracts, respectively, using Brilliant II SYBR Green qPCR Master mix (Aligent technologies, Santa Clare, CA, US). The thermal cycling programme was: $95^{\circ} \mathrm{C}$ for $15 \mathrm{~min}$ followed 40 cycles of $95^{\circ} \mathrm{C}$ for $15 \mathrm{~s}$ and $62^{\circ} \mathrm{C}$ for $1 \mathrm{~min}$. Changes in gene expression were examined using the $2^{-\Delta \Delta} \mathrm{Ct}$ method [30]. Expression levels were normalised to RPS20 or RPS29 and calculated as a ratio with NT samples or vehicle controls set to 1 .

\section{Culture of TGCT-derived NTera2 cell line}

The TGCT-derived embryonal carcinoma cell line NTera2 was a kind gift from Professor Peter Andrews (University of Sheffield, UK) [31]. The NTera2 cells were cultured according to standard culture conditions. In brief, cells were cultured in DMEM supplemented with $10 \%$ fetal bovine serum, glutamine $(58.5 \mathrm{mg} / \mathrm{ml})$, penicillin $(100 \mathrm{U} / \mathrm{ml})$ and streptomycin $(100 \mathrm{mg} / \mathrm{ml})$ at $37^{\circ} \mathrm{C}$ in a $5 \% \mathrm{CO}_{2}$ atmosphere. Cell media and reagents were from Gibco (Invitrogen, Carlsbad, CA, US). For gene expression analyses and co-treatment experiments, the ALK4/5/7 inhibitor SB431542 [32] that simultaneously inhibits Nodal and Activin signalling $(40 \mu \mathrm{M}, 20 \mu \mathrm{M}$, $10 \mu \mathrm{M}, 4 \mu \mathrm{M})$, recombinant Nodal $(50 \mathrm{ng} / \mathrm{ml})$, recombinant Activin $(50 \mathrm{ng} / \mathrm{ml})$, recombinant Lefty $(100 \mathrm{ng} / \mathrm{ml})$, recombinant Follistatin $(100 \mathrm{ng} / \mathrm{ml})$ and cisplatin (1 and $5 \mu \mathrm{M}$, stock solution $1 \mathrm{mg} / \mathrm{ml}$ dissolved in $0.9 \% \mathrm{NaCl}$ from EberwePharma, Unterach am Attersee, Austria) were added to the media. SB431542 was dissolved in DMSO, while Nodal, Activin, Lefty and Follistatin were dissolved in PBS with $0.1 \%$ BSA or $4 \mathrm{mM} \mathrm{HCl}, 0.1 \%$ BSA in PBS. The recombinant proteins were purchased from R\&D systems (Minneapolis, MN, US), while SB431542 was purchased from Sigma Aldrich (St. Louis, MO, US). Cells were plated in $25 \mathrm{~cm}^{2}$ flasks (Nunc, Thermo Fisher), incubated overnight before treatment was initiated and during the treatment period cells were split every $48 \mathrm{~h}$ with complete media change. Half of the cells were plated in new $25 \mathrm{~cm}^{2}$ flasks and the other half were collected for analysis. NTera2 cells used for immunohistochemical analysis were grown on glass slides (Nunc ${ }^{\mathrm{mm}}$ Lab-Tek $^{\text {mit }}$ II Chamber Slide ${ }^{\text {tw }}$ System) for $48 \mathrm{~h}$ followed by fixation in $4 \%$ formalin. Slides were stored at $4{ }^{\circ} \mathrm{C}$ until further analysis.

\section{Cell proliferation assay}

Proliferation of NTera 2 cells was determined after $24 \mathrm{~h}$ and 48 h treatment with SB431542, and after co-treatments with SB431542 or recombinant Lefty and cisplatin. Proliferation was evaluated using the WST-1 assay according to the manufacturer's instructions (Roche, Basel, Schweiz). 10,000 NTera2 cells were seeded into a 96-well plate with sixteen replicates of each sample and incubated overnight. Cells were then treated with SB431542 $(5 \mu \mathrm{M}, 10 \mu \mathrm{M}$ and $20 \mu \mathrm{M})$ or vehicle control (0.1\% DMSO) for $24 \mathrm{~h}$ and $48 \mathrm{~h}$. To assess proliferation, 1:10 WST-1 dye (Roche) in serum-free DMEM was added to the cells for $2 \mathrm{~h}$ before absorbance was measured at $450 \mathrm{~nm}$ and $630 \mathrm{~nm}$ using a FLUOstar Omega microplate reader (BMG Labtech, Ortenberg, Germany) or an Epoch Microplate Spectrophotometer (Biotek, Brøndby, Denmark). For co-treatments, 4000 cells/well were plated into 96-well plates with eight replicates of each sample and allowed to attach for $6 \mathrm{~h}$. Treatment with SB431542 (5 $\mu \mathrm{M}$ and $20 \mu \mathrm{M})$, recombinant Lefty (100 ng/ $\mathrm{ml})$ or vehicle control (0.1\% DMSO) was then initiated for $48 \mathrm{~h}$. Subsequently, media were removed and replaced with media containing cisplatin $(1 \mu \mathrm{M}$ and $5 \mu \mathrm{M})$ or $0.9 \% \mathrm{NaCl}$ for $48 \mathrm{~h}$. Cell proliferation was assessed with the WST-1 assay as described above.

\section{Ex vivo culture of adult human testis samples}

Testis tissue samples (NT/GCNIS) obtained from orchiectomised testicular cancer patients (described above) were set up ex vivo in hanging drop cultures as described previously [33], with a few modifications. In brief, hanging drops were set up using $40 \mu$ drops of culture medium \pm treatment with addition of a single testicular fragment $\left(1 \mathrm{~mm}^{3}\right)$ per drop and complete media change every $48 \mathrm{~h}$. Nine tissue fragments were set up for each treatment. Medium composition was: DMEM:F12, penicillin $(100 \mathrm{U} / \mathrm{ml})$, streptomycin (100 
$\mathrm{mg} / \mathrm{ml})$, insulin, transferrin, selenium $(\times 1)$ and $10 \%$ fetal bovine serum. Media and supplements were all purchased from Gibco. Cultures were incubated for $48 \mathrm{~h}$ and 4 days at $34{ }^{\circ} \mathrm{C}$ in $5 \% \mathrm{CO}_{2} .6 \mathrm{~h}$ before the end of the culture period, the testis pieces were incubated with BrdU-labelling reagent (Invitrogen). Subsequently, tissue fragments were fixed in $4 \%$ formalin.

\section{siRNA-mediated knockdown of CRIPTO expression}

siRNA-mediated knockdown was carried out as previously described [12]. siRNA specific for CRIPTO (TDGF1HSS144243, Invitrogen), a non-specific siRNA control (MISSION siRNA Universal Negative Control, SICOO1, Sigma Aldrich) and transfection agent RNAiMAX Lipofectamine (Life Technologies, Carlsbad, CA, US) was used. In brief, $1 \times 10^{6}$ NTera2 cells were seeded into a 6-well plate and at the time of transfection cells were approximately $60-70 \%$ confluent. A concentration of $50 \mathrm{nM}$ siRNA was used. $24 \mathrm{~h}$ after transfection, cells were re-plated into a 96-well plate (4000 cells/well) or cultured in T- $25 \mathrm{~cm}^{2}$ flasks for RNA extractions. After $48 \mathrm{~h}$, media were removed from the 96-well plate and replaced with media containing cisplatin $(1 \mu \mathrm{M}$ or $5 \mu \mathrm{M})$ or $0.9 \% \mathrm{NaCl}$ for $48 \mathrm{~h}$. Cell proliferation was determined by the WST-1 assay as described above.

\section{Establishment of NTera2 xenografts and treatments in NMRI nude mice}

The establishment and experiments conducted in this model were set up by technicians at Pipeline Biotech A/S (Trige, Denmark). Animal experiments were conducted in compliance with the Danish Animal Experiments Inspectorate (license number 2011/561-1956) as previously described [10, 34], with few modifications. Briefly, 30 NMRI male mice $\left(\right.$ Fox $^{\text {nul }}$ ) aged 6-8 weeks (Janvier labs, Le Genest-Saint-Isle, France) were injected once with $2 \times 10^{6}$ NTera2 cells into each flank. When the tumours reached an approximate size of $150 \mathrm{~mm}^{3}$, the mice were randomly allocated into three treatment groups of ten animals; treatment group 1 , cisplatin $(6 \mathrm{mg} / \mathrm{kg}$ i.p. once during experiment), treatment group 2, cisplatin + SB431542 $(6 \mathrm{mg} / \mathrm{kg}$ cisplatin i.p. once during experiment and $10 \mathrm{mg} / \mathrm{kg}$ SB431542 i.p. 3 times weekly) and treatment group 3, vehicle $(10 \mathrm{mg} / \mathrm{kg}$ DMSO i.p. 3 times weekly). Treatment groups 1 and 3 were also used in a separate study to reduce the total number of animals included (Lorenzen et al, unpublished). Body weight and tumour volume were measured 3 times weekly throughout the experimental period of 14 days. Tumour volume was calculated as: tumour volume $=$ length $\times$ width $\times 1 / 2$ width. At the end of the experiment mice were euthanized by inhalation of $\mathrm{CO}_{2}$ followed by cervical dislocation. The mice were caged in European standard cages type II with Jeluxyl HW 300/ 500 bedding and the housing and changing system was designed to assure that MPF-status was preserved during the study. The air was exchanged approximately 12 times per hour and temperature was kept between $20^{\circ} \mathrm{C}$ and $24^{\circ} \mathrm{C}$ (controlled via the ambient ventilation system). Light cycle was 12-h dark and 12-h light. During the entire experimental period mice were fed ad libitum with Standard diet (Altromin 1234, 600 IE D3/kg diet; Altromin, Lage, Germany) and UV-sterilised water were administered ad libitum. All animals were inspected on a daily basis for their general condition. Any animal showing clinical signs of moderate pain or distress, any degree of suffering or clinical signs that exceed the limits of the study specific end-point would have been humanely euthanized according to the European and Danish legislation on animals in experimental studies.

\section{Statistical analysis}

Statistical analysis was performed using the Software GraphPad Prism 8 (San Diego, CA, US). Differences in gene expression and cell proliferation were tested using a two-tailed Student's t-test, while differences in tumour growth were tested using a one-way ANOVA with Bonferroni correction. Statistically significant differences are indicated as $* P<0.05$, ** $P<0.01$ and $* * * 0.001$. The number of replicates in each experimental set-up and statistical significance are specified in figure legends.

\section{Results}

Expression of Nodal signalling factors in normal testis, GCNIS, testicular tumours and NTera2 cells

The expression levels of NODAL, CRIPTO and LEFTY1 were initially investigated by RT-qPCR in tissue from adult testis samples with full spermatogenesis and no presence of malignant germ cells (hereafter termed 'normal testis' (NT)), samples containing pre-invasive GCNIS cells in the majority of tubules (GCNIS), seminoma tumour (SEM), embryonal carcinoma tumour $(E C)$ and teratoma tumour (TER). OCT4 (POU5F1) and NANOG were included to verify the neoplastic content in GCNIS, SEM and EC samples. Overall, the investigated Nodal pathway genes were all expressed in the included samples, but at very different levels (Supplementary Fig. 1a). In GCNIS, SEM and EC, the expression of OCT4 (GCNIS, SEM, $P<0.05$; EC, $P<0.001$ ) and NANOG (all $P<0.05$ ) was significantly increased compared to NT, verifying the neoplastic content within these samples. The expression of Nodal signalling factors NODAL $(P<0.001)$, CRIPTO $(P<0.05)$ and LEFTY1 $(P<$ 0.001 ) was significantly higher in EC samples compared to NT as well as GCNIS, SEM and TER.

Protein expression of NODAL, CRIPTO and LEFTY (antibody detects both LEFTY1 and LEFTY2) was examined by immunohistochemistry in serial sections of NT, GCNIS, SEM and EC. OCT4 was included as a marker of malignant germ cells, and was detected in GCNIS, SEM and EC, but not in NT which is in accordance with the 
expected expression pattern (Supplementary Fig. 1b). NODAL, CRIPTO and LEFTY were expressed in all investigated samples, except NT. The expression of all three Nodal pathway proteins was more pronounced in EC compared to GCNIS and SEM, with co-expression of all three proteins in $\mathrm{OCT}^{+} \mathrm{EC}$ cells. Interestingly, the expression of NODAL, CRIPTO and LEFTY was found only in a subpopulation of GCNIS cells and expression in these cells was low. Additionally, the expression pattern of NODAL, CRIPTO, LEFTY and OCT4 was also examined in the ECderived NTera2 cell line (Supplementary Fig. 1c). Noticeably, CRIPTO was strongly expressed in the nuclei in addition to the expected cytoplasmic/membranous expression. NODAL was expressed in the cytoplasm, whereas LEFTY appeared to be present between adjacent NTera2 cells, possibly reflecting secretion from the cells.

\section{Effects of simultaneous inhibition of Nodal and Activin} signalling on proliferation and transcriptional expression in NTera2 cells

In order to investigate the effects of inhibiting Nodal and Activin signalling on proliferation of NTera2 cells, treatment experiments with the ALK4/5/7 inhibitor SB431542 [32], were conducted. Treatment with $20 \mu \mathrm{M}$, $10 \mu \mathrm{M}$ and $5 \mu \mathrm{M}$ SB431542 had no significant effect $(P>0.05)$ on proliferation of NTera2 cells after $24 \mathrm{~h}$ or $48 \mathrm{~h}$ (Fig. 1a-b). In contrast, treatment with SB431542 $(40 \mu \mathrm{M}, 20 \mu \mathrm{M}$ and $4 \mu \mathrm{M})$ for $48 \mathrm{~h}$ resulted in significantly lower expression of pluripotency factors OCT4 $(40 \mu \mathrm{M}$ and $20 \mu \mathrm{M}, P<0.01,4 \mu \mathrm{M}, P<0.05)$ and NANOG $(P<0.001)$ as well as NODAL, CRIPTO and LEFTY1 (all $P<0.001$ ) in NTera2 cells (Fig. 1c). After 7 days of treatment with SB431542 $(40 \mu \mathrm{M}, 20 \mu \mathrm{M}$ and $4 \mu \mathrm{M})$, expression of all investigated genes remained significantly reduced (Fig. 1d).

\section{Effects of manipulating Nodal and Activin signalling} separately on the transcriptional expression pattern in NTera2 cells and ex vivo cultures of adult testis tissue To separate the effects of inhibiting or stimulating Nodal and Activin signalling pathways individually, a series of treatment experiments were performed in the NTera2 cell line. The Nodal pathway was stimulated by treatment with recombinant Nodal $(50 \mathrm{ng} / \mathrm{ml})$ and inhibited

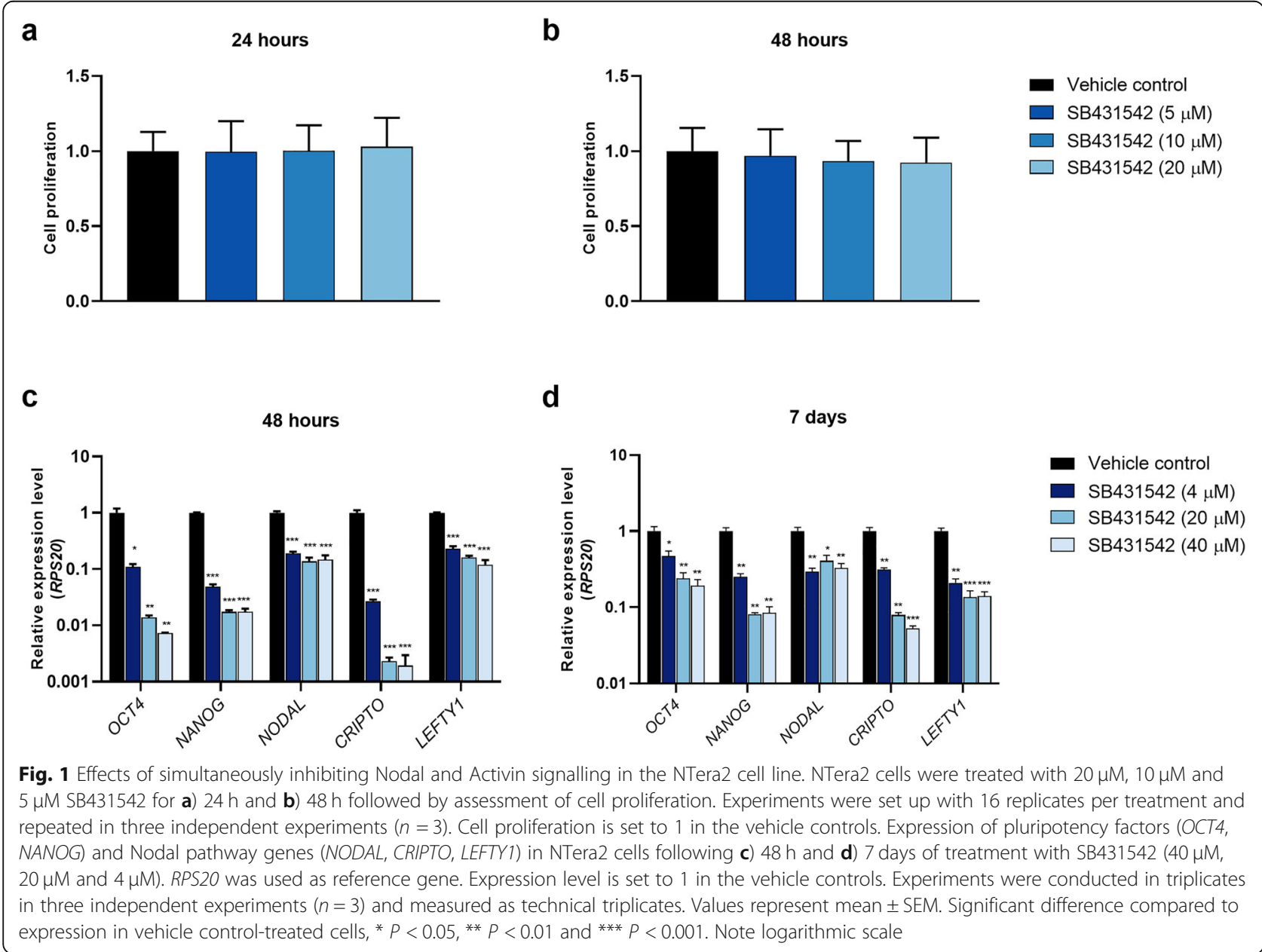


by treatment with recombinant Lefty $(100 \mathrm{ng} / \mathrm{ml})$. Nodal treatment for $48 \mathrm{~h}$ resulted in a significant upregulation of OCT4 $(P<0.05)$ and NANOG $(P<0.01)$ as well as NODAL $(P<0.001)$, CRIPTO $(P<0.01)$ and LEFTY1 $(P<0.001)$ (Fig. 2a). The expression of OCT4 and CRIPTO (both $P<$ $0.01)$ remained upregulated after 7 days of treatment with recombinant Nodal (Fig. 2b). In contrast, Lefty treatment for $48 \mathrm{~h}$ significantly reduced the expression level of all investigated genes; OCT4 $(P<0.05), N O D A L(P<0.05)$, NANOG $(P<0.01)$, CRIPTO $(P<0.01)$ and LEFTY1 $(P<$ $0.001)$ (Fig. 2a). The expression of OCT4 $(P<0.01)$, NANOG $(P<0.001)$, NODAL $(P<0.01)$, CRIPTO $(P<0.01)$ and LEFTY1 $(P<0.001)$ continued to be downregulated following Lefty treatment for 7 days (Fig. 2b). The Activin pathway was stimulated using recombinant Activin A (50 $\mathrm{ng} / \mathrm{ml}$ ) and inhibited using recombinant Follistatin (100 ng/ $\mathrm{ml})$. Activin treatment resulted in significantly higher expression of NANOG $(P<0.05)$ and LEFTY1 $(48 \mathrm{~h}, P<0.05$; 7 days, $P<0.01$ ) at both $48 \mathrm{~h}$ and 7 days (Fig. $2 \mathrm{c}-\mathrm{d}$ ), with increased expression of CRIPTO $(P<0.05)$ also after $48 \mathrm{~h}$. Follistatin treatment increased only the expression of NANOG $(P<0.05)$ after $48 \mathrm{~h}$.
To examine the effects of manipulating Nodal and Activin signalling in malignant germ cells preserved within their somatic niche, the effects of SB431542, recombinant Nodal and Activin A were investigated in cultures of primary testis tissue from testicular cancer patients (Fig. 3 and Fig. 4). Tissue containing tubules with GCNIS cells (located adjacent to the TGCT tumour in the orchiectomised testis) from three patients was cultured ex vivo for $48 \mathrm{~h}$ (Fig. 3) and 4 days (Fig. 4). None of the treatments significantly affected $(P>0.05)$ proliferation $\left(\mathrm{BrdU}^{+} /\right.$ $\mathrm{mm}^{2}$ ), apoptosis $\left(\mathrm{cPARP}^{+} / \mathrm{mm}^{2}\right)$ or number of GCNIS cells $\left(\mathrm{OCT}^{+} / \mathrm{mm}^{2}\right)$ compared to the vehicle controls after $48 \mathrm{~h}$ (Fig. 3b-e) or 4 days (Fig. 4a-d).

\section{Effects of pharmaceutical inhibition of Nodal and Activin signalling on cisplatin-sensitivity in NTera2 cells}

To determine whether co-treatment with inhibitors of the Nodal signalling pathway affects cisplatin-sensitivity, NTera2 cells were treated with SB431542 $(5 \mu \mathrm{M}$ and $20 \mu \mathrm{M})$ or recombinant Lefty $(100 \mathrm{ng} / \mathrm{ml})$ for $48 \mathrm{~h}$ followed by $48 \mathrm{~h}$ of cisplatin treatment $(1 \mu \mathrm{M}$ and $5 \mu \mathrm{M})$. Subsequently, effects on cell proliferation was assessed.

\section{a}

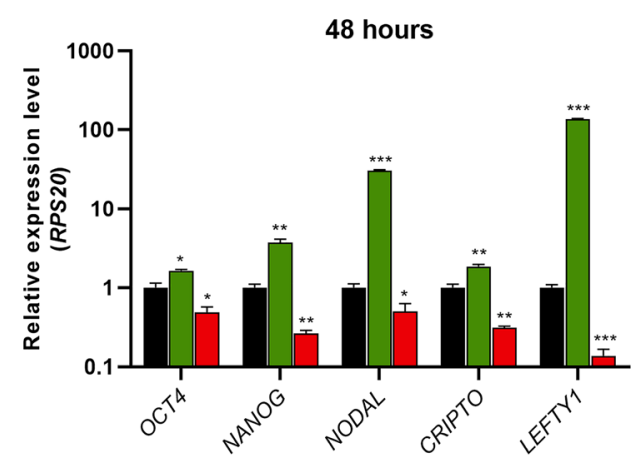

C

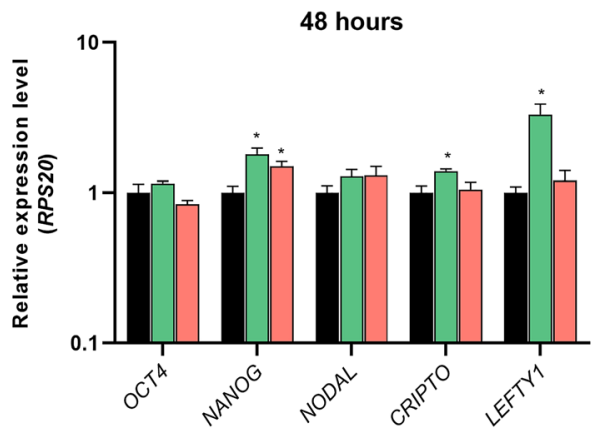

b

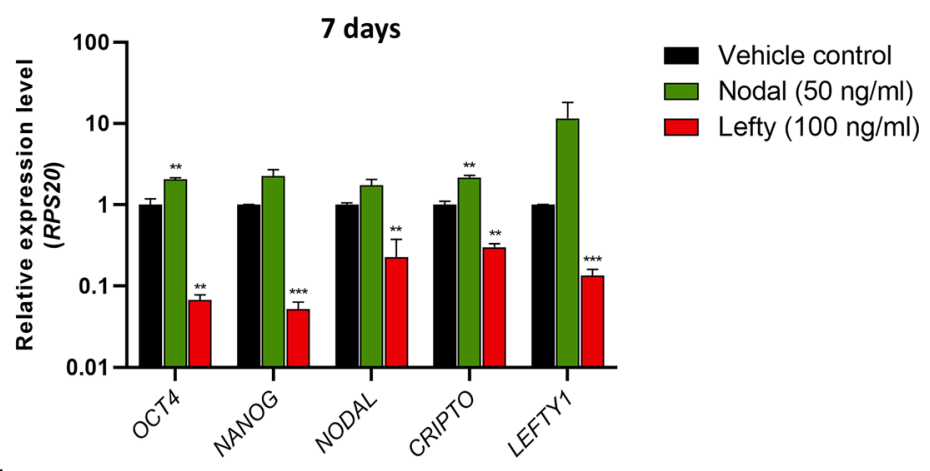

d

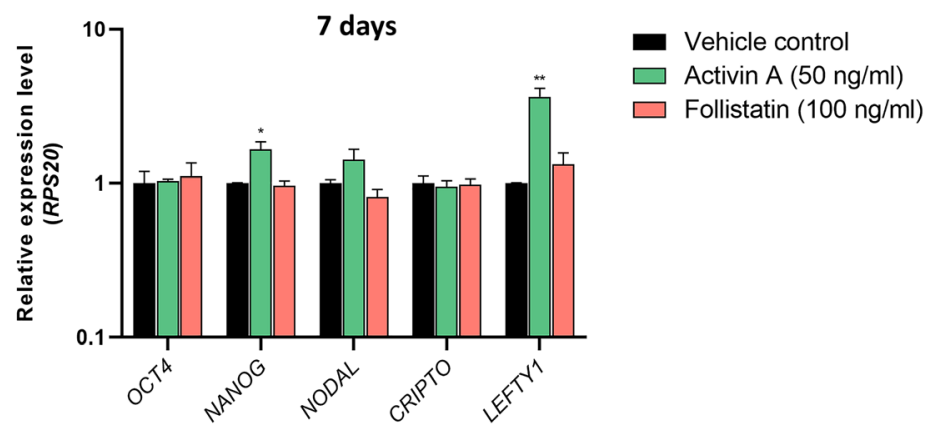

Fig. 2 Effects of manipulating Nodal and Activin signalling separately in NTera2 cells. Expression of pluripotency factors (OCT4, NANOG) and Nodal signalling factors (NODAL, CRIPTO, LEFTY1) in NTera2 cells following a) $48 \mathrm{~h}$ and b) 7 days of treatment with recombinant Nodal $(50 \mathrm{ng} / \mathrm{ml})$ and Lefty $(100 \mathrm{ng} / \mathrm{ml})$ and c) $48 \mathrm{~h}$ and d) 7 days of treatment with Activin A $(50 \mathrm{ng} / \mathrm{ml})$ and Follistatin $(100 \mathrm{ng} / \mathrm{ml})$. RPS 20 was used as reference gene. Expression level is set to 1 in the vehicle controls. Experiments were conducted in triplicates in three independent experiments $(n=3)$ and measured as technical triplicates. Values represent mean \pm SEM. Significant difference compared to expression in vehicle control-treated cells, * $P<0.05$, ** $P<0.01$ and ${ }^{* *} P<0.001$. Note logarithmic scale 


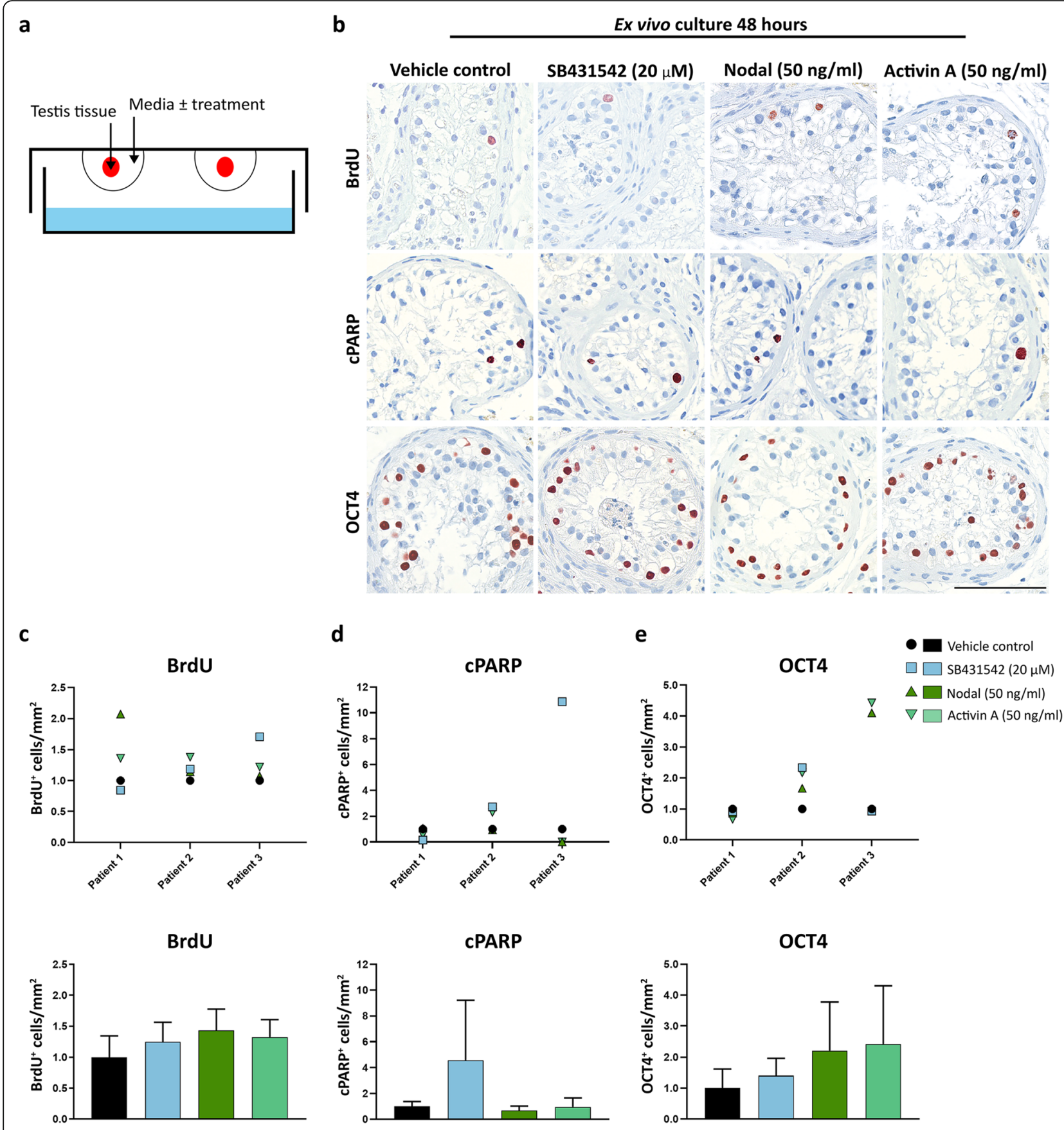

Fig. 3 Effects of manipulating Nodal and Activin signalling in GCNIS cells cultured ex vivo for 48 h. a) Schematic illustration of the experimental ex vivo hanging drop culture approach. b) Immunohistochemical staining with BrdU (proliferation marker), CPARP (apoptosis marker) and OCT4

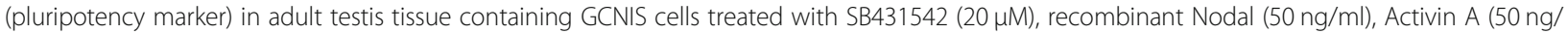
$\mathrm{ml}$ ) or vehicle for $48 \mathrm{~h}$. Sections were counterstained with Mayer's haematoxylin. Scale bar corresponds to $100 \mu \mathrm{m}$. Quantification of the number of c) $\mathrm{BrdU}^{+}$cells per $\mathrm{mm}^{2}$, d) $\mathrm{CPARP}^{+}$cells per $\mathrm{mm}^{2}$ and e) $\mathrm{OCT}^{+}$cells per $\mathrm{mm}^{2}$. Number of positive cells is normalised to vehicle controls (set to 1), and only apoptotic GCNIS cells were quantified. Tissue from three patients was evaluated $(n=3)$. Top panel of $\mathbf{c}$-e) shows results from the individual patient samples, while bottom panel represents mean \pm SEM

Co-treatments were conducted in three independent experiments, with similar results obtained between the experiments (Fig. 5a). Overall, initial exposure to SB431542 or Lefty followed by cisplatin treatment did not affect the cisplatin-sensitivity in the NTera2 cells. However, cotreatment with $20 \mu \mathrm{M}$ SB431542 and $1 \mu \mathrm{M}$ cisplatin significantly increased $(P<0.05)$ proliferation compared to cells treated with $1 \mu \mathrm{M}$ cisplatin only, indicating that 


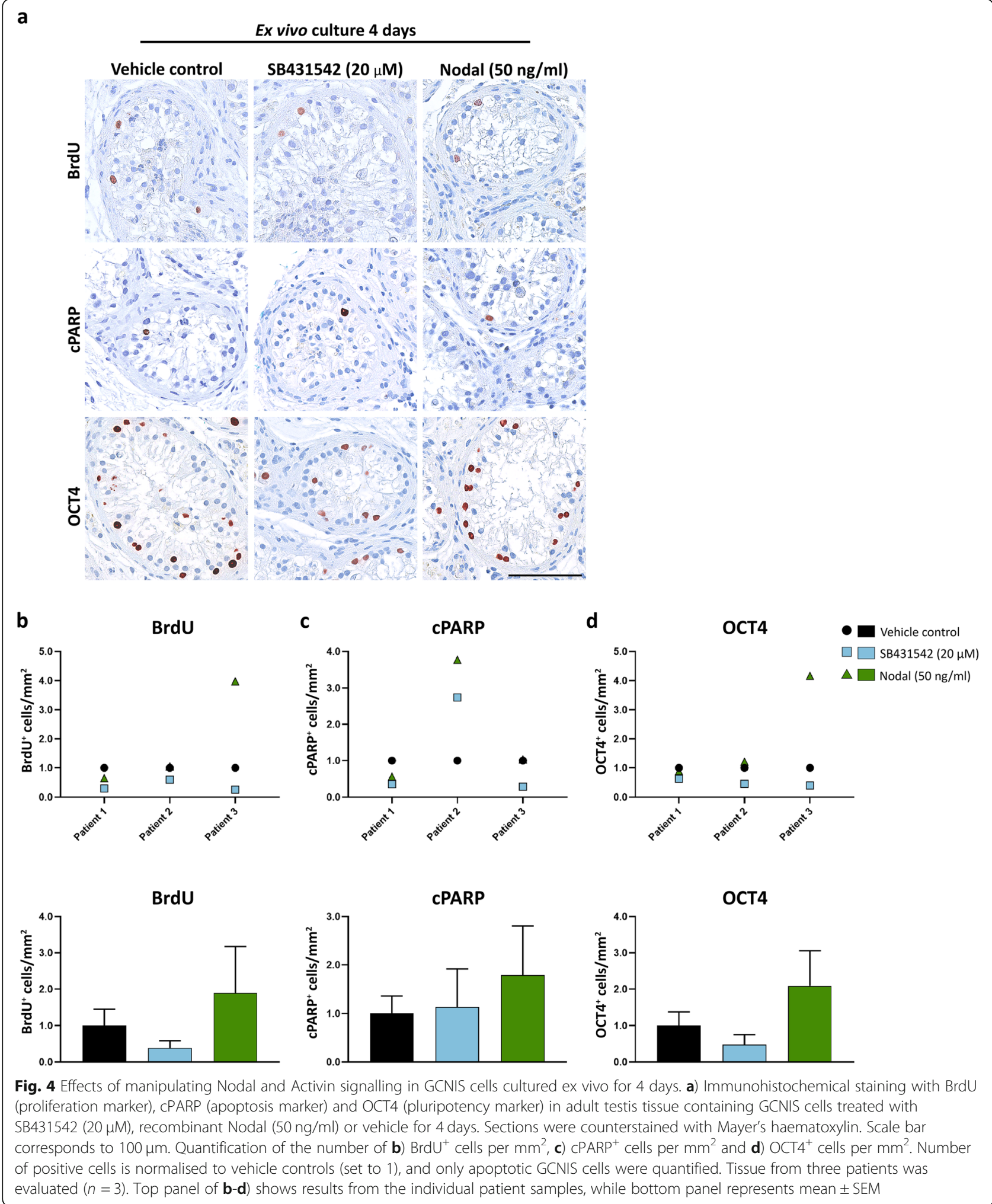

the cells were less sensitive to the cisplatin treatment (Fig. 5b). Generally, there was a tendency towards reduced cisplatin-sensitivity when cells were co-treated with SB431542 and cisplatin regardless of the doses used, although for most combinations of doses this was not statistically significant $(P>0.05)$. 


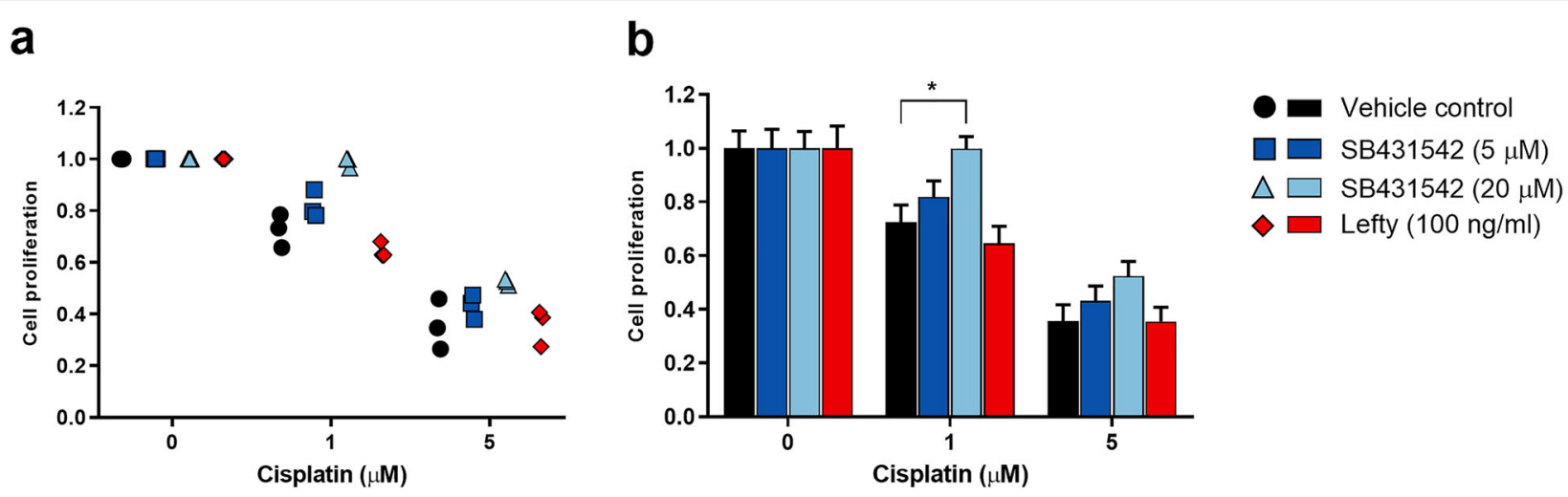

Fig. 5 Effects of pharmaceutical inhibition of Nodal/Activin or Nodal signalling on cisplatin-sensitivity in NTera2 cells. NTera2 cells were treated for $48 \mathrm{~h}$ with SB431542 $(5 \mu \mathrm{M}$ and $20 \mu \mathrm{M})$ or Lefty $(100 \mathrm{ng} / \mathrm{ml})$ followed by additional $48 \mathrm{~h}$ of cisplatin treatment $(1 \mu \mathrm{M}$ and $5 \mu \mathrm{M})$ and assessment of cell proliferation. a) Experiments were conducted in three independent experiments with eight replicates per treatment (shown as mean for each experiment). Cell proliferation is set to 1 in NTera2 cells not treated with cisplatin. b) Values represent mean \pm SEM from the three independent experiments $(n=3)$. Significant difference compared to proliferation of vehicle-treated control NTera2 cells receiving corresponding cisplatin treatment, $* P<0.05$

\section{Effects of siRNA-mediated knockdown of CRIPTO} expression on cisplatin-sensitivity in NTera2 cells In order to examine whether the tendency towards reduced cisplatin-sensitivity found after inhibition of Nodal signalling (with SB431542) could be verified, the effect of CRIPTO knockdown on cisplatin-sensitivity was examined. Expression of the co-receptor CRIPTO, obligate for Nodal signalling, was knocked down in NTera2 cells by a siRNA approach. Subsequently, NTera2 cells were treated with cisplatin $(1 \mu \mathrm{M}$ and $5 \mu \mathrm{M})$ for $48 \mathrm{~h}$ and cell proliferation was assessed. The expression of CRIPTO was significantly reduced $(P<0.05)$ upon transfection with siCRIPTO compared to the siCTRL (Fig. 6a-b) in all individual experiments and when combined. Despite the significant reduction in CRIPTO expression $(P<0.05)$, no effect on cisplatin-sensitivity was found in the NTera2 cells when compared to the siCTRL-transfected NTera2 cells treated with cisplatin (Fig. 6c-d).

\section{Effects of simultaneous inhibition of Nodal and Activin signalling on cisplatin-sensitivity in a NTera2 xenograft mouse model}

Simultaneous inhibition of Nodal and Activin signalling by SB431542 treatment in combination with cisplatin treatment was subsequently investigated in an NTera2 xenograft mouse model. NTera2 cells were injected into the flanks of nude mice and after the development of tumours, treatment was initiated. The animals were treated with either cisplatin alone, a combination of cisplatin + SB431542 or vehicle control. None of the animals exhibited observable negative effects of the experimental procedure or treatments. In the vehicle-treated control mice, tumour burden continued to increase throughout the experimental period (Fig. 7), while in mice treated with cisplatin alone and cisplatin + SB431542, the tumour size was significantly reduced $(P<$
0.01 and $P<0.001)$ compared to the vehicle controls already 3 days after the treatments were initiated. However, no significant difference $(P>0.05)$ in tumour size was found between mice treated with cisplatin alone and cisplatin + SB431542 at any of the evaluated time-point (Fig. 7).

\section{Discussion}

In the present study, we found high expression of the Nodal signalling factors in undifferentiated types of TGCTs and our results suggest that the Nodal pathway may be involved in the regulation of pluripotency factor expression in malignant germ cells. However, targeting Nodal signalling in the EC-derived NTera2 cell line by several different experimental approaches did not affect proliferation of the malignant germ cells or result in any pronounced effects on cisplatin-sensitivity, indicating that the Nodal pathway may not represent a promising clinical target to augment the effect of current chemotherapy regimens in testicular cancer patients.

NODAL, CRIPTO and LEFTY1/2 were expressed at transcript and protein levels in GCNIS cells and the undifferentiated TGCTs, SEM and EC. The most pronounced expression of all Nodal pathway factors was found in EC and co-expressed in $\mathrm{OCT}_{4}^{+}$cells. In accordance with previous studies $[14,16,18]$, the expression of Nodal factors in 'normal' testis without malignant cells was low/absent, suggesting maintenance of Nodal factor expression in GCNIS and/or re-activation in malignant germ cells. Additionally, the overall expression of the Nodal factors at both gene and protein levels in GCNIS and SEM was lower compared to EC which is in accordance with a previous study [18]. Interestingly, the protein expression of the Nodal pathway factors was less pronounced in GCNIS cells compared to EC but also to some extent SEM, which supports the notion that Nodal signalling components 


\section{a}

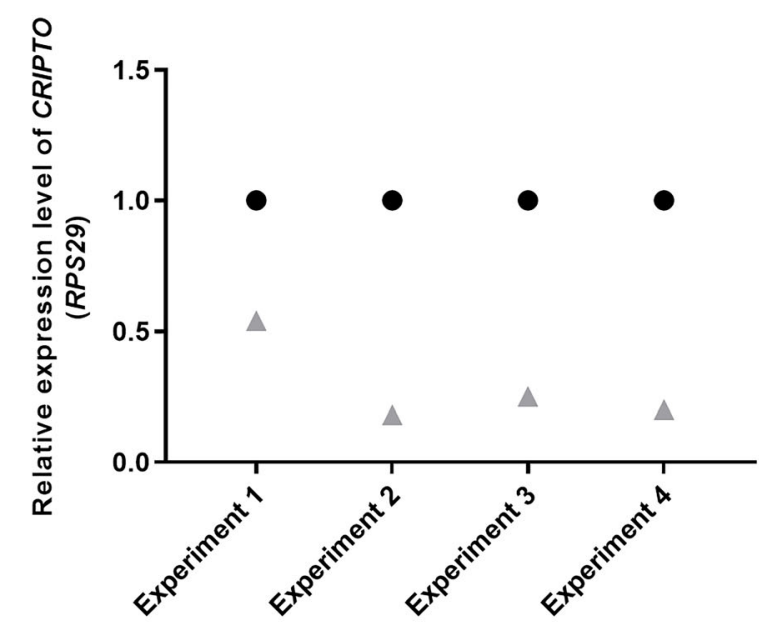

C

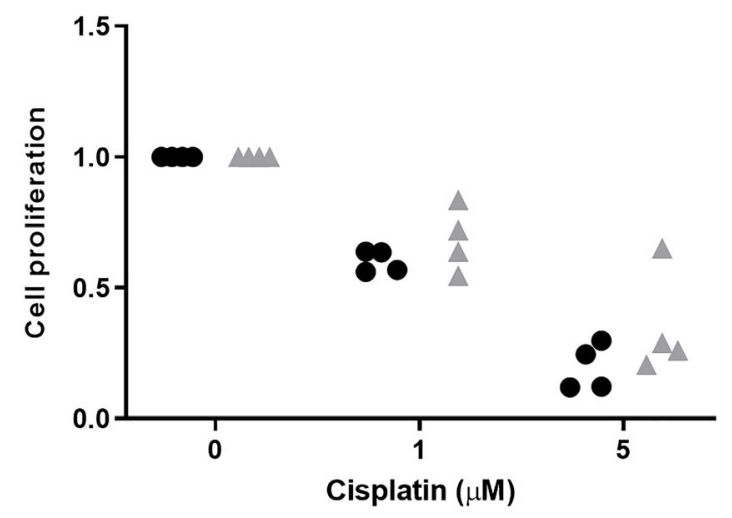

b

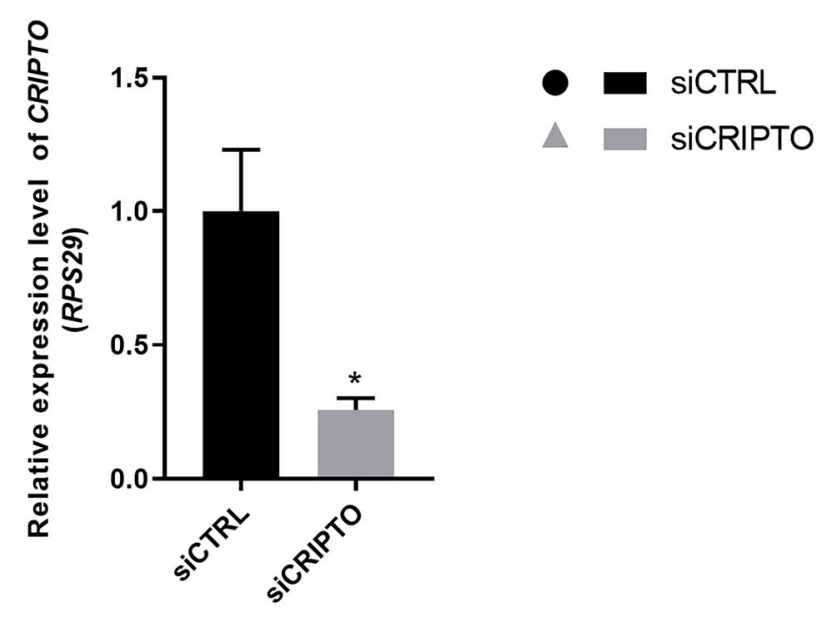

d

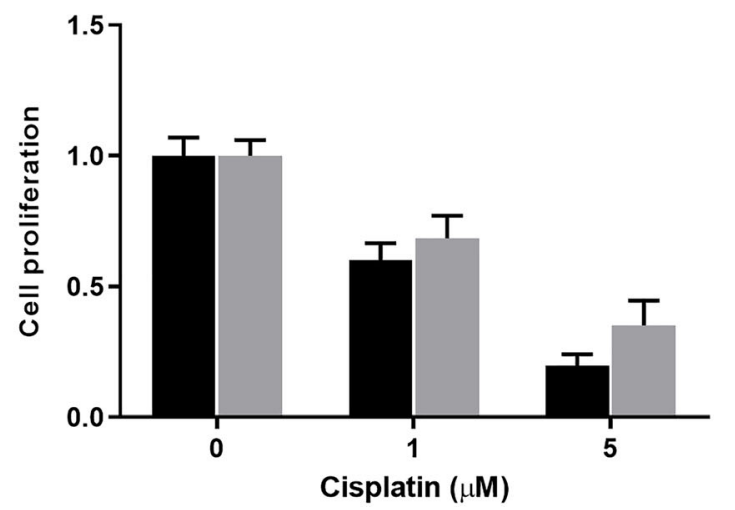

Fig. 6 Effects of siRNA-mediated knockdown of CRIPTO expression on cisplatin-sensitivity in NTera2 cells. Expression of CRIPTO determined by RTqPCR after knockdown using a siRNA targeting CRIPTO (siCRIPTO) and a non-specific siRNA control (siCTRL). RPS29 was used as reference gene. a) Experiments were conducted in four independent experiments $(n=4)$ and measured as technical triplicates (shown as mean for each experiment). Expression level of CRIPTO is set to 1 in vehicle-treated control NTera2 cells. b) Values represent mean \pm SEM from the four independent experiments. Significant difference compared to expression level of CRIPTO in siCTRL-transfected NTera2 cells, ${ }^{*} P<0.05$. Following knockdown, cells were subjected to treatment with $1 \mu \mathrm{M}$ and $5 \mu \mathrm{M}$ cisplatin for $48 \mathrm{~h}$ and cell proliferation was assessed. c) Experiments were conducted in four independent experiments and set up with eight technical replicates per treatment. d) Values represent mean \pm SEM from the four independent experiments. Cell proliferation is set to 1 in vehicle-treated control NTera2 cells not treated with cisplatin

might be maintained only at low levels in GCNIS cells and are upregulated in the invasive tumours, although it remains to be determined whether the Nodal pathway is involved in the transition from GCNIS to EC/(SEM). The observed high expression of LEFTY1/2 in undifferentiated TGCTs, indicates that the inhibitory feedback mechanism on Nodal signalling may not be dysregulated in TGCTs, despite a previous study suggested this based on the reported low expression of LEFTY1 in EC [16].

The Nodal signalling factors were all expressed in the NTera2 cell line, hence we used it as a model to examine effects of manipulating Nodal signalling in TGCTs. Simultaneous inhibition of Nodal and Activin pathways did not affect proliferation in NTera2 cells or in GCNIS cells in ex vivo cultured testis samples. Since Nodal and Activin signalling have been implicated in germ cell survival in both human and mouse fetal testes [19, 35], this may indicate a difference between normal fetal gonocytes and malignant germ cells, although it is important to consider that in contrast to normal fetal germ cells, malignant TGCTs have acquired features allowing them to survive outside of their normal niche. In the NTera2 cells, simultaneous inhibition of Nodal and Activin signalling resulted in reduced expression of the investigated pluripotency factors and Nodal pathway genes, and after separating the effects of Nodal and Activin signalling 


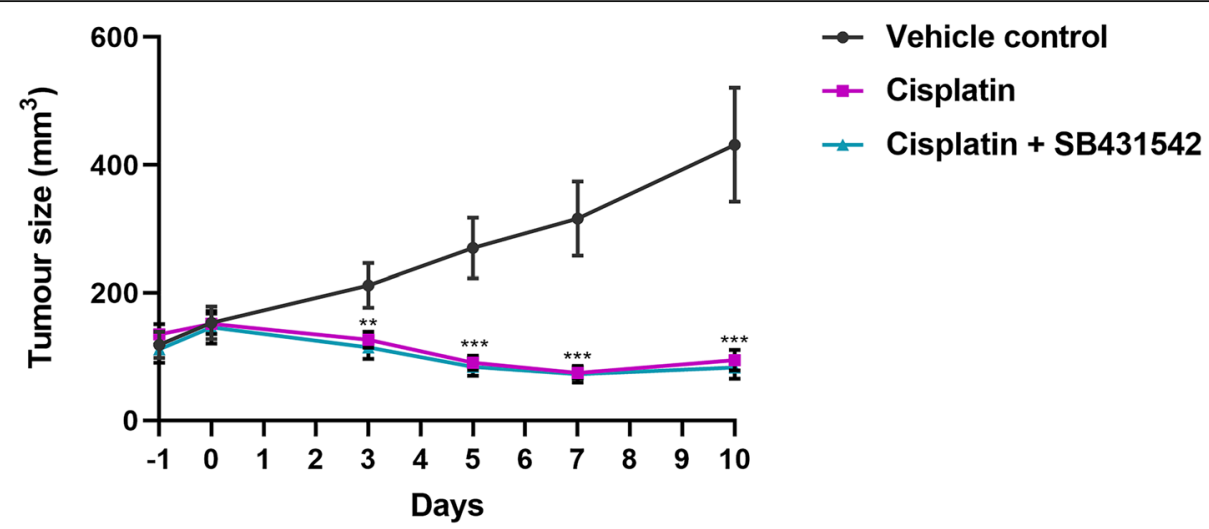

Fig. 7 Effects of inhibiting Nodal/Activin signalling on cisplatin-sensitivity in a NTera2 xenograft model. NTera2 cells $\left(2 \times 10^{6}\right.$; single injection) were xenografted into the flanks of nude mice and allowed to grow to an average size of $150 \mathrm{~mm}^{3}$. Animals were allocated into three groups $(n=10 \mathrm{for}$ each group) and treated (day 0 on graph) with vehicle (10 mg/kg DMSO i.p. three times weekly), cisplatin (6 mg/kg i.p. once during the experiment) or cisplatin + SB431542 (6 mg/kg cisplatin i.p. once during the experiment and $10 \mathrm{mg} / \mathrm{kg}$ SB431542 i.p. three times weekly). Body weight and tumour size $\left(\mathrm{mm}^{3}\right)$ were evaluated three times weekly during the experimental period of 11 days. Values represent mean \pm SEM. Significant difference compared to vehicle control-treated mice, ${ }^{*} P<0.05,{ }^{* *} P<0.01$ and ${ }^{* *} P<0.001$. Abbreviations: i.p., intraperitoneal injection

pathways it was evident that the Nodal pathway was responsible for the majority of observed effects. Additionally, the opposing effects observed after stimulating and inhibiting Nodal signalling, suggest that the pathway may be involved in the regulation of pluripotency factor expression in malignant germ cells. These results are in accordance with the reported involvement of Nodal signalling in regulating pluripotency factor expression in human fetal testes [19], mouse fetal testes [16, 36, 37] and human embryonic stem cells [38]. However, manipulation of Nodal and Activin signalling in ex vivo cultures of GCNIS-containing tissue ( $48 \mathrm{~h}$ and 4 days) did not overall affect the number of OCT4 ${ }^{+}$GCNIS cells, although in one patient sample an increased number of $\mathrm{OCT}^{+}$GCNIS cells was observed following treatment with Nodal and Activin (48 h) and Nodal (4 days). The different responses between patient samples as well as the relative short-term culture periods used in this study, suggest that additional studies examining the effects of stimulated Nodal/Activin signalling on GCNIS cells may be relevant. Importantly, the overall low number of apoptotic germ cells and the presence of proliferating cells in the cultured tissue samples, suggest that the tissue was supported by the culture approach and that the selected treatment doses were not toxic. However, given the high variation in the tissue, which is expected in testicular cancer patients [33], minor effects of treatments can be difficult to detect using this experimental approach.

Aberrant re-activation of Nodal signalling has been reported in various types of cancers, including cancer stem cells which also express pluripotency factors, and several studies have shown that inhibition of Nodal/(Activin) signalling reduces the tumorigenic potential both in vitro and in cancer mouse models [22-26]. Additionally, combined treatment with the SB431542 inhibitor and chemotherapy (gemcitabine) abolished tumours in a pancreatic cancer mouse model and resulted in complete survival of mice in this treatment group [24]. Moreover, given the almost complete germ cell loss following SB431542 treatment of human fetal testes, we examined whether co-treatment with this inhibitor could augment cisplatin-sensitivity in NTera2 cells. Overall, we did not observe pronounced effects on cisplatin-sensitivity following inhibition of Nodal signalling in vitro or in the xenograft model, except tendencies toward reduced cisplatin-sensitivity after in vitro pharmaceutical inhibition of Nodal/Activin signalling and siRNA-mediated knockdown of the obligate co-receptor CRIPTO. In vitro treatment with recombinant Lefty to inhibit only Nodal signalling did not result in reduced cisplatin-sensitivity (or showed tendencies in this direction), which could reflect the different levels at which inhibitory molecules and siRNA-mediated knockdown functions [39]. Additionally, the slightly increased cisplatin-resistance observed following blockage of both Nodal and Activin signalling (using the high dose of SB431542), but not after specific inhibition of Nodal signalling, could indicate some redundancy between the Nodal and Activin pathways. We speculate that inhibition of Nodal signalling promotes downregulation of pluripotency factor expression in the malignant germ cells driving them towards a more differentiated phenotype, which is associated with reduced cisplatin-sensitivity [8-12]. However, since both ECs (high Nodal expression) and SEMs (low Nodal expression) are highly sensitive to cisplatin-based treatment $[6,7]$, this may explain why we did not find pronounced effects on cisplatin-sensitivity upon manipulation of the Nodal signalling pathway. It has previously been demonstrated that calcitriol treatment (active form of vitamin D) 
of NTera2 cells resulted in both decreased expression of pluripotency factors and augmented effects of cisplatin, while treatment of NTera2 with retinoic acid decreased the expression of pluripotency factors and reduced cisplatin-mediated effects $[10,34]$. This suggests that the relationship between pluripotency factor expression and cisplatin-sensitivity in malignant germ cells is not completely understood and that further studies examining this would be relevant.

\section{Conclusions}

In conclusion, the Nodal signalling factors are highly expressed in the undifferentiated types of TGCTs and may be involved in the regulation of pluripotency factor expression in malignant germ cells. In contrast to several other types of cancers in which the Nodal pathway is also reactivated, inhibition of Nodal (and Activin) signalling did not affect tumour cell proliferation or augment cisplatinsensitivity in TGCTs in vitro or in the xenograft model. Thus, the different response to the pharmaceutical pathway inhibitor SB431542 in TGCTs compared to human fetal germ cells, suggests that regulation or feedback mechanisms related to the Nodal pathway may be altered in malignant germ cells, although additional studies are needed to examine these mechanisms in more detail.

\section{Supplementary information}

Supplementary information accompanies this paper at https://doi.org/10. 1186/s12885-020-06820-6.

Additional file 1: Figure S1. Expression of Nodal signalling factors in testis, GCNIS cells, TGCTs and TGCT-derived NTera2 cells. a) Expression level of OCT4, NANOG, NODAL, CRIPTO and LEFTY1 in testis tissue with complete spermatogenesis and no malignant germ cells (NT), testis samples containing GCNIS cells (GCNIS), seminoma tumour (SEM), embryonal carcinoma (EC) and teratoma (TER) examined by RT-qPCR. RPS20 was used as reference gene. Expression level is set to 1 in NT samples. Tissue samples from eight patients were included $(n=8)$ and measured as technical duplicates. Values represent mean \pm SEM. Significant difference compared to expression in NT samples, ${ }^{*} P<0.05$, ${ }^{* *} P<0.01$ and ${ }^{* * *} P<$ 0.001. Note logarithmic scale. $b-c)$ Expression of Nodal signalling factors NODAL, CRIPTO and LEFTY (antibody detects both LEFTY1 and LEFTY2) determined by immunochemical analysis in serial sections of NT, GCNIS, SEM and EC and TGCT-derived NTera2 cells. OCT4 is included as a marker of malignant germ cells. Sections were counterstained with Mayer's haematoxylin. Scale bars correspond to $50 \mu \mathrm{m}$ (b) and $100 \mu \mathrm{m}$ (c).

\section{Abbreviations}

CHC: Choriocarcinoma; EC: Embryonal carcinoma; GCNIS: Germ cell neoplasia in situ; i.p.: Intraperitoneal injection; Non-SEM: Non-seminoma; NT: Normal testis; SEM: Seminoma; TER: Teratoma; TGCTs: Testicular germ cell tumours; YST: Yolk sac tumour

\section{Acknowledgements}

The authors wish to thank the technicians from the Department of Growth and Reproduction, especially the excellent help from Ana Ricci Nielsen, Camilla Tang Thomsen and Brian Vendelbo Hansen is gratefully acknowledged. We appreciate the help from staff at the Urology Department and Pathology Department in provision of testicular tissue.

\section{Authors' contributions}

Conceived and designed the experiments: KHP, AJØ. Performed the experiments: KHP, JEN. Analysed the data: KHP, LJR, MBJ, RTM, AJU, ERDM, AJØ. Contributed reagents/materials/analysis tools and expertise: BGT, UNJ. Wrote the manuscript: KHP, AJØ. All authors approved the submitted version.

\section{Funding}

This work was supported in part by an ESPE Research Fellowship, sponsored by Novo Nordisk A/S to A. Jørgensen. Additional funding for this project was obtained from The Danish Cancer Society (Grant no: R72-A4335-13-S2, AJø), The Erichssen Family Fund (A」ø), Dagmar Marshalls Fund (AJø) and Aase \& Ejnar Danielsens Fund (AJø). The funders had no involvement in the design of the study or in collection, analysis, and interpretation of data as well as in writing the manuscript.

\section{Availability of data and materials}

The data to support the findings of this study are available upon reasonable request from the corresponding author, but restrictions apply to the availability of these data, which were used under license for the current study, and so are not publicly available.

Ethics approval and consent to participate

Ethical approval was obtained for collection of human testis samples from University Hospital of Copenhagen (Rigshospitalet), Copenhagen, Denmark (H-1-2012-007). Written and informed consent was obtained for the use of all tissues included in the study. Animal experiments were approved prior to the beginning of the study and were conducted by Pipeline Biotech in compliance with the Danish Animal Experiments Inspectorate (license number 2011/561-1956).

\section{Consent for publication}

The study involves the use of tissues from anonymised and non-identifiable patients.

\section{Competing interests}

The authors declare that they have no competing interests.

\section{Author details}

'Department of Growth and Reproduction, Copenhagen University Hospital (Rigshospitalet), Blegdamsvej 9, DK-2100 Copenhagen, Denmark. ${ }^{2}$ International Research and Research Training Centre in Endocrine Disruption of Male Reproduction and Child Health (EDMaRC), Blegdamsvej 9, Copenhagen, Denmark. ${ }^{3}$ Pathology Department, Copenhagen University Hospital (Rigshospitalet), Blegdamsvej 9, 2100 Copenhagen, Denmark. ${ }^{4}$ Department of Urology, Copenhagen University Hospital (Rigshospitalet), Blegdamsvej 9, 2100 Copenhagen, Denmark. ${ }^{5}$ Department of Cellular and Molecular Medicine, Center for Healthy Aging, University of Copenhagen, Blegdamsvej 3B, 2200 Copenhagen, Denmark. ${ }^{6}$ MRC Centre for Reproductive Health, The Queen's Medical Research Institute, University of Edinburgh, 47 Little France Crescent, Edinburgh EH16 4TJ, UK.

Received: 14 February 2020 Accepted: 2 April 2020

Published online: 23 April 2020

\section{References}

1. Skakkebaek NE. Possible carcinoma-in-situ of the testis. Lancet (London, England). 1972;2:516-7. https://doi.org/10.1016/s0140-6736(72)91909-5.

2. Skakkebaek NE, Berthelsen JG, Giwercman A, Müller J. Carcinoma-in-situ of the testis: possible origin from gonocytes and precursor of all types of germ cell tumours except spermatocytoma. Int J Androl. 1987;10:19-28. https:// doi.org/10.1111/j.1365-2605.1987.tb00161.x.

3. Rajpert-De Meyts E. Developmental model for the pathogenesis of testicular carcinoma in situ: genetic and environmental aspects. Hum Reprod Update. 2006;12:303-23. https://doi.org/10.1093/humupd/dmk006.

4. Ulbright TM, Amin MB, Balzer B, Berney DM, Epstein Jl, Guo C, Idrees MT, Looijenga LHJ, Paner G, Rajpert-De Meyts E, Skakkebaek NE, Tickoo SK, Yilmaz A, and Oosterhuis JW, in WHO Classification of Tumours of the Urinary System and Male Genital Organs, 4th edn., ed. by H. Moch, P.A. Humphrey, T.M. Ulbright. Germ cell tumours (IARC Press, Lyon, 2016), 189-226. 
5. Rajpert-De Meyts E, McGlynn KA, Okamoto K, Jewett MAS, Bokemeyer C. Testicular germ cell tumours. Lancet. 2016;387:1762-74. https://doi.org/10. 1016/S0140-6736(15)00991-5.

6. Jacobsen C, Honecker F. Cisplatin resistance in germ cell tumours: models and mechanisms. Andrology. 2015;3:111-21. https://doi.org/10.1111/andr.299.

7. Singh R, Fazal Z, Freemantle SJ, Spinella MJ. Mechanisms of cisplatin sensitivity and resistance in testicular germ cell tumors. Cancer Drug Resist (Alhambra, Calif.). 2019;2:580-94 https://doi.org/10.20517\%2Fcdr.2019.19.

8. Oosterhuis JW, Looijenga LHJ. Human germ cell tumours from a developmental perspective. Nat Rev Cancer. 2019;19:522-37. https://doi.org/ 10.1038/s41568-019-0178-9

9. Mueller T, Mueller LP, Luetzkendorf J, Voigt W, Simon H, Schmoll HJ. Loss of Oct-3/4 expression in embryonal carcinoma cells is associated with induction of cisplatin resistance. Tumor Biol. 2006;27:71-83. https://doi.org/ $10.1159 / 000092324$.

10. Jørgensen A, Blomberg Jensen M, Nielsen JE, Juul A, Rajpert-De Meyts E. Influence of vitamin D on cisplatin sensitivity in testicular germ cell cancerderived cell lines and in a NTera2 xenograft model. J Steroid Biochem Mol Biol. 2013;136:238-46. https://doi.org/10.1016/j.jsbmb.2012.10.008.

11. Abada PB, Howell SB. Cisplatin induces resistance by triggering differentiation of testicular embryonal carcinoma cells. PLoS One. 2014;9: e87444. https://doi.org/10.1371/journal.pone.0087444.

12. Rudolph C, Melau C, Nielsen JE, Vile Jensen K, Liu D, Pena-Diaz J, Rajpert-De Meyts E, Rasmussen $L$, Jørgensen A. Involvement of the DNA mismatch repair system in cisplatin sensitivity of testicular germ cell tumours. Cell Oncol. 2017;40:341-55. https://doi.org/10.1007/s13402-017-0326-8.

13. Feldman DR, Bosl GJ, Sheinfeld J, Motzer RJ. Medical treatment of advanced testicular cancer. JAMA. 2008;299:672-84. https://doi.org/10. 1001/jama.299.6.672.

14. Baldassarre G, Romano A, Armenante F, Rambaldi M, Paoletti I, Sandomenico C, Pepe S, Staibano S, Salvatore G, De Rosa G, Persico MG, Viglietto $\mathrm{G}$. Expression of teratocarcinoma-derived growth factor-1 (TDGF-1) in testis germ cell tumors and its effects on growth and differentiation of embryonal carcinoma cell line NTERA2 / D1. Oncogene. 1997;15:927-36. https://doi.org/10.1038/sj.onc.1201260.

15. Watanabe K, Meyer MJ, Strizzi L, Lee JM, Gonzales M, Bianco C, Nagaoka T, Farid SS, Margaryan N, Hendrix MJC, Vonderhaar BK, Salomon DS. Cripto-1 is a cell surface marker for a tumorigenic, undifferentiated subpopulation in human Embryonal carcinoma cells. Stem Cells. 2010;28:1303-14. https://doi. org/10.1002/stem.463.

16. Spiller CM, Feng CW, Jackson A, Gillis AJM, Rolland AD, Looijenga LHJ, Koopman $\mathrm{P}$, Bowles J. Endogenous nodal signaling regulates germ cell potency during mammalian testis development. Development. 2012;139: 4123-32. https://doi.org/10.1242/dev.083006.

17. Spiller CM, Gillis AJM, Burnet G, Stoop H, Koopman P, Bowles J, Looijenga LHJ. Cripto: Expression, epigenetic regulation and potential diagnostic use in testicular germ cell tumors. Mol Oncol. 2015;30:1-12. https://doi.org/10. 1016/j.molonc.2015.11.003.

18. Nettersheim D, Jostes $S$, Sharma R, Schneider S, Hofmann A, Ferreira HJ, Hoffmann P, Kristiansen G, Esteller MB, Schorle H. BMP inhibition in seminomas initiates Acquisition of Pluripotency via NODAL signaling resulting in reprogramming to an Embryonal carcinoma. PLoS Genet. 2015; 11:1-26. https://doi.org/10.1371/journal.pgen.1005415.

19. Jørgensen A, Macdonald J, Nielsen JE, Kilcoyne KR, Perlman S, Lundvall L, Langhoff Thuesen L, Juul Hare K, Frederiksen H, Andersson AM, Skakkebæk NE, Juul AR, Sharpe M, Rajpert-De Meyts E, Mitchell RT. Nodal Signaling Regulates Germ Cell Development and Establishment of Seminiferous Cords in the Human Fetal Testis. Cell Reports. 2018;25:1924-1937.e4. https://doi. org/10.1016/j.celrep.2018.10.064.

20. Harpelunde Poulsen $\mathrm{K}$, Jorgensen A. Role of Nodal signalling in testis development and initiation of testicular cancer. Reproduction (Cambridge, England). 2019;158:R67-77. https://doi.org/10.1530/REP-18-0641.

21. Cheng SK, F., Olale BAH, Schier AF. Lefty blocks a subset of TGF $\beta$ signals by antagonizing EGF-CFC coreceptors. PLoS Biology. 2004;2:e30 https://doi. org/10.1371\%2Fjournal.pbio.0020030.

22. Topczewska JM, Postovit LM, Margaryan NV, Sam A, Hess AR, Wheaton WW, Nickoloff BJ, Topczewski J, Hendrix MJC. Embryonic and tumorigenic pathways converge via nodal signaling: role in melanoma aggressiveness. Nat Med. 2006;12:925-32. https://doi.org/10.1038/nm1448.

23. Lawrence MG, Margaryan NV, Loessner D, Collins A, Kerr KM, Turner M, Seftor EA, Stephens CR, Lai J, BioResource APC, Postovit LM, Clements JA,
Hendrix MJC. Reactivation of embryonic nodal signaling is associated with tumor progression and promotes the growth of prostate cancer cells. Prostate. 2011;71:1198-209 https://doi.org/10.1002\%2Fpros.21335.

24. Lonardo $\mathrm{E}_{\text {, et }}$ al. Nodal/activin signaling drives self-renewal and tumorigenicity of pancreatic cancer stem cells and provides a target for combined drug therapy. Cell Stem Cell. 2011;9:433-46. https://doi.org/10. 1016/j.stem.2011.10.001.

25. Strizzi L, Hardy KM, Margaryan NV, Hillman DW, Seftor EA, Chen B, Geiger XJ, Thompson EA, Lingle WL, Andorfer CA, Perez EA, Hendrix MJC. Potential for the embryonic morphogen nodal as a prognostic and predictive biomarker in breast cancer. Breast Cancer Res. 2012;14:R75. https://doi.org/10.1186/bcr3185.

26. Gong W, Sun B, Sun H, Zhao X, Zhang D, Liu T, Zhao N, Gu Q, Dong X and Liu F. Nodal signaling activates the $S$ mad2/3 pathway to regulate stem celllike properties in breast cancer cells. Am J Cancer Res 2017;7:503-517. PMID: 28401007.

27. Rajpert-De Meyts E, Nielsen JE, Skakkebæk NE, Almstrup K. Diagnostic markers for germ cell neoplasms: from placental-like alkaline phosphatase to micro-RNAs. Folia Histochem Cytobiol. 2015;53(3):177-88. https://doi.org/ 10.5603/FHC.a2015.0020.

28. Jørgensen A, Nielsen JE, Blomberg Jensen M, Græm N, Rajpert-De Meyts E. Analysis of meiosis regulators in human gonads: a sexually dimorphic spatio-temporal expression pattern suggests involvement of DMRT1 in meiotic entry. Mol Hum Reprod. 2012;18:523-34. https://doi.org/10.1093/ molehr/gas030.

29. Svingen T, Jørgensen A, Rajpert-De Meyts E. Validation of endogenous normalizing genes for expression analyses in adult human testis and germ cell neoplasms. Mol Hum Reprod. 2014;20:709-18. https://doi.org/10.1093/ molehr/gau030.

30. Livak KJ, Schmittgen TD. Analysis of relative gene expression data using real-time quantitative PCR and the 2(-Delta Delta C(T)) Method, Methods (San Diego, Calif.). 2001;25:402-8. https://doi.org/10.1006/meth.2001.1262.

31. Andrews PW, Damjanov I, Simon D, Banting GS, Carlin C, Dracopoli NC, Fogh J. Pluripotent embryonal carcinoma clones derived from the human teratocarcinoma cell line Tera-2: differentiation in vivo and in vitro. Lab Investig. 1984;50:147-62.

32. Inman GJ, Nicolás FJ, Callahan JF, Harling JD, Gaster LM, Reith AD, Laping NJ, Hill CS. SB-431542 is a potent and specific inhibitor of transforming growth factor-beta superfamily type I Activin receptor-like kinase (ALK) receptors ALK4, ALK5, and ALK7. Mol Pharmacol. 2002;62:65-74. https://doi. org/10.1124/mol.62.1.65.

33. Jørgensen A, Young J, Nielsen JE, Joensen UN, Toft BG, Rajpert-De Meyts E, Loveland KL. Hanging drop cultures of human testis and testis cancer samples: a model used to investigate activin treatment effects in a preserved niche. $\mathrm{Br} J$ Cancer. 2014;110:2604-14. https://doi.org/10.1038/bjc.2014.160.

34. Blomberg Jensen M, Jørgensen A, Nielsen JE, Steinmeyer A, Leffers $H$, Juul A, Rajpert-De Meyts E. Vitamin D Metabolism and effects on Pluripotency genes and cell differentiation in testicular germ cell tumors in vitro and in vivo. Neoplasia. 2012;14:952-63 https://doi.org/10.1593\%2Fneo.121164.

35. Wu Q, Kanata K, Saba R, Deng CX, Hamada H, Saga Y. Nodal/activin signaling promotes male germ cell fate and suppresses female programming in somatic cells. Development. 2013;140:291-300. https://doi. org/10.1242/dev.087882.

36. Miles DC, Wakeling SI, Stringer JM, van den Bergen JA, Wilhelm D, Sinclair $\mathrm{AH}$, Western PS. Signaling through the TGF Beta-Activin receptors ALK4/5/7 regulates testis formation and male germ cell development. PLoS One. 2013;8:1-16 https://doi.org/10.1371\%2Fjournal.pone.0054606.

37. Tian-Zhong M, Bi C, Ying Z, Xia J, Cai-Ling P, Yun-Shan Z, Mei-Wen H, YanRu N. Critical role of Emx2 in the pluripotency - differentiation transition in male gonocytes via regulation of FGF9/NODAL pathway. Reproduction. 2016;151:673-81. https://doi.org/10.1530/REP-16-0022.

38. Vallier L, Reynolds D, Pedersen RA. Nodal inhibits differentiation of human embryonic stem cells along the neuroectodermal default pathway. Dev Biol. 2004;275:403-21. https://doi.org/10.1016/j.ydbio.2004.08.031.

39. Weiss WA, Taylor SS, Shokat KM. Recognizing and exploiting differences between RNAi and small-molecule inhibitors. Nat Chem Biol. 2007;3:739-44. https://doi.org/10.1038/nchembio1207-739.

\section{Publisher's Note}

Springer Nature remains neutral with regard to jurisdictional claims in published maps and institutional affiliations. 